referring clinician we always give the probability as well so that he may rely less on the result the lower the probability.

Though the computed diagnosis was compared with the general clinical opinion, we could not compare systematically the computed diagnoses directly with those of any one clinician in all cases. Such a comparison performed on 20 selected patients from the district hospitals showed that the model performed as well as the most accurate of five clinicians and better than the least accurate. ${ }^{14}$

The proposed improvements to the data base and diagnostic matrix of the model should improve its accuracy even further, though even now it can give much help in reaching the correct diagnosis in difficult cases of jaundice. We have also found that rather than replacing the clinician such a system may stimulate him to be more thorough and make more use of those data which the computer finds highly discriminating but which are not always those given in textbooks of clinical medicine.

We are extremely grateful to the physicians and surgeons who have allowed us access to their patients and who have co-operated in this project. We also thank B. Leventhal for his help with computer programming. R.B.S. is in receipt of a Bernard Sunley Research Fellowship from the Royal College of Physicians, London.

\section{References}

1 Knill-Jones, R., et al., British Medical fournal, 1973, 1, 530.

Overall, J. E., and Williams, C. M., Fournal of the American Medical Association, 1963, 183, 307.

3 Boyle, A. J., et al., Quarterly fournal of Medicine, 1966, 35, 565.

Rinaldo, J. A., Scheinok, P., and Rupe, C. E., Annals of Internal Medicine, $1963,59,145$.

5 Warner, H. R., et al., fournal of the American Medical Association, 1961, 177, 177 .

${ }^{6}$ Nugent, C. A., Warner, H. R., and Dunn, J. T., fournal of Clinical Endocrinology, 1964, 24, 621.

7 Hywel-Jones, J., et al., Quarterly fournal of Medicine, 1973, 168, 715.

8 de Dombal, F. T., et al., British Medical fournal, 1972, 2, 9.

9 Horrocks, J. C., et al., British Medical fournal, 1972, 2, 5.

o Horrocks, J. C., et al., British Medical fournal, 1972, 2, 5 .

11 Fraser, P. M., and Franklin, D. A., Quarterly fournal of Medicine, 1974, 169,73 .

12 Dudley, H. A. F., Lancet, 1968, 2, 723.

13 Dudley, H. A. F., Lancet, 1968, 2, 723.

14 Anders, R. B., Knill-Jones, R., and Williams, R., Methods and Information Stern, R. B., Knill-Jones, $R$.
in Medicine, 1974, 13, 79.

\title{
Use of Biochemical Profile in Children's Hospital: Results of Two Controlled Trials
}

\author{
J. V. LEONARD, BARBARA E. CLAYTON, J. R. T. COLLEY
}

British Medical fournal, 1975, 2, 662-665

\section{Summary}

Two controlled trials of the use of a biochemical profile were conducted in a children's hospital to see whether the profile led to diagnoses which would not otherwise have been made and to see what effect it had on the number of extra requests for pathological investigations and the length of stay in hospital. Altogether 2816 children were examined and 13 new diagnoses made. There was a significant increase in the total number of pathology requests but the profile did not alter the length of stay in hospital. We conclude that the profile made only a small contribution to the overall care of the patients.

\section{Introduction}

Studies of the effects of providing biochemical profiles for adults have shown that unsuspected abnormalities may be discovered which are responsible for new diagnoses. ${ }^{1-3}$ Between $3 \%$ and $10 \%$ of the patients were thought to have benefited from the profile. Our aim was to see what effect a profile would have on children, as no such studies had been reported. Two controlled trials were conducted on two groups of children

The Hospital for Sick Children, Great Ormond Street, London WC1 J. V. LEONARD, M.B., M.R.C.P., Research Fellow, D epartment of Chemical Pathology

Institute of Child Health, London WC1N 1EH

BARBARA E. CLAYTON, M.D., F.R.C.PATH., Professor of Chemical Pathology

London School of Hygiene and Tropical Medicine, London WC1E 7HT J. R. T. COLLEY, M.D., M.F.C.M., Reader in Paediatric Epidemiology admitted to hospital. The major objective was to measure the use the clinicians made of the information in the profile in terms of the number of diagnoses attributable to the profile, the number of extra pathology requests, and the length of stay in hospital.

\section{Methods}

The biochemical profile had 14 components, of which 12 (sodium, potassium, total $\mathrm{CO}_{2}$, urea, calcium, phosphorus, alkaline phosphatase, total protein, albumin, reducing sugar, cholesterol, and aspartate aminotransferase (SGOT) were measured on a multichannel analyser (Technicon SMA 12/micro). Haemoglobin and magnesium were estimated by a semi-automated cyanmethaemoglobin method and atomic absorption spectroscopy respectively. The 14 tests required a total of $0.7 \mathrm{ml}$ of blood. An evaluation of the SMA 12/micro during the study, including details of the methods and the results of the quality control, has been reported. ${ }^{4}$

The study was conducted for a total of 39 weeks between 2 January and 21 December 1973. The remaining 11 weeks were lost for various reasons, in particular because of problems with the SMA 12/micro. All patients admitted to The Hospital for Sick Children during the 39 weeks were eligible for inclusion in the study except for day cases and those admitted to two surgical wards. Blood was usually collected within 72 hours of admission, no attempt being made to collect it with the child fasting. Most specimens were analysed the same day, but if not the plasma was stored at $4^{\circ} \mathrm{C}$ until assayed. Some children had a blood transfusion or operation before blood could be drawn, and no specimen was taken from these patients. The consultants gave written permission for patients to be included in the study, but if they wished they or a deputy could still exclude any patient.

\section{DESIGN OF TRIALS}

Two trials were designed which ran simultaneously. On admission the eligible children were allocated to one or other trial.

Trial A (Early and Late Groups).-All patients admitted for medical treatment, all emergency cases, and all patients admitted for routine surgical procedures who were expected to stay for more than 
one week were entered into trial A. All had a biochemical profile constructed and were allocated at random to one of two groups. In one the results of the profile were sent out the day the blood was analysed (early), and in the other the results were sent out on the eighth hospital day (late). In both groups the blood was usually collected and analysed within four days of admission. Analyses not completed within this time are excluded from our final assessment

Trial B (Profile and Control Groups).-Surgical patients expected to stay for less than one week were included in trial B and allocated at random before admission to either a "profile" group (in which a complete profile was constructed) or a control group (in which only the haemoglobin was measured). The results in this trial were sent out the day the blood was analysed. Results not sent out by the third hospital day are excluded from our final assessment.

The clinicians were unaware to which trial or group within a trial their patients had been allocated. Throughout the study the clinicians continued to request in the routine way all the tests they needed, including those in the profile. Results outside predetermined limits (table I) were sent to the clinician as soon as possible when he had not requested the test independently, and the child was taken out of the trial. These children form the "immediate" group.

TABLE I-Limits for Results to be Released Immediately to Clinician (Immediate Group)

\begin{tabular}{|c|c|c|c|c|c|}
\hline \multirow{2}{*}{\multicolumn{3}{|c|}{ Component }} & \multirow{2}{*}{ Units } & \multicolumn{2}{|c|}{ Limits } \\
\hline & & & & Lower & Upper \\
\hline $\begin{array}{l}\text { Sodium .. } \\
\text { Potassium } \\
\text { Total CO, } \\
\text { Calcium (if und } \\
\text { Calcium (if und } \\
\text { weeks old) }\end{array}$ & 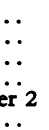 & $\begin{array}{l}\because \\
\cdots \\
\cdots \\
\ldots\end{array}$ & $\begin{array}{l}\mathrm{mmol} / \mathrm{l} \\
\mathrm{mmol} / \mathrm{l} \\
\mathrm{mmol} / \mathrm{l} \\
\mathrm{mmol} / \mathrm{l} \\
\mathrm{mmol} / \mathrm{l}\end{array}$ & $\begin{array}{c}115 \\
2 \cdot 0 \\
10 \cdot 0 \\
1 \cdot 87 \\
1 \cdot 25\end{array}$ & $\begin{array}{l}155 \\
7.0 \\
3.0 \\
3.0\end{array}$ \\
\hline $\begin{array}{l}\text { Sugar } \quad . . \\
\text { Urea } \\
\text { Magnesium } \\
\text { Haemoglobin }\end{array}$ & $\begin{array}{l}\because \\
\cdots \\
\cdots\end{array}$ & $\begin{array}{l}\cdots \\
\cdots \\
\cdots\end{array}$ & $\begin{array}{l}\mathrm{mmol} / \mathrm{l} \\
\mathrm{mmol} / \mathrm{l} \\
\mathrm{mmol} / \mathrm{l} \\
\mathbf{g} / \mathrm{dl}\end{array}$ & $\begin{array}{l}1.66 \\
0.41 \\
8.9\end{array}$ & $\begin{array}{c}11 \cdot 1 \\
16 \cdot 6 \\
1.23 \\
\end{array}$ \\
\hline
\end{tabular}

\section{EFFECT OF PROFILE}

To discover what use the clinicians made of the profile the case notes were inspected by one of us (J.V.L.) at least three months after admission. The notes of all patients in trial $B$ were examined. In trial A the case notes of those with one or more outlying results were studied, as time did not allow the notes of every child to be examined.

The ranges used to identify outlying values were derived from the frequency distributions of the results obtained during the first three months of the study. The aim was to find the cut-off points which excluded approximately the upper and lower $5 \%$ of the distribution. Some estimations (for example, phosphorus) which show a trend

TABLE II-Distribution of Profiles Within Trials

\begin{tabular}{|c|c|c|c|c|c|}
\hline \multicolumn{3}{|c|}{ Group } & Boys & Girls & Total \\
\hline $\begin{array}{l}\text { Early } \\
\text { Late }\end{array}$ & $\because$ & 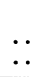 & $\begin{array}{l}712 \\
666\end{array}$ & $\begin{array}{l}528 \\
524\end{array}$ & $\begin{array}{l}1240 \\
1190\end{array}$ \\
\hline \multicolumn{3}{|c|}{ Total } & 1378 & 1052 & 2430 \\
\hline \multirow[t]{2}{*}{$\begin{array}{l}\text { Profile } \\
\text { Control }\end{array}$} & $\because$ & 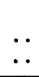 & $\begin{array}{l}247 \\
243\end{array}$ & $\begin{array}{l}139 \\
160\end{array}$ & $\begin{array}{l}386 \\
403\end{array}$ \\
\hline & \multicolumn{2}{|c|}{ Total } & 490 & 299 & 789 \\
\hline
\end{tabular}

with age were divided into six age groups; the upper and lower $5 \%$ points were then determined for each of these. As the purpose of these limits was to identify patients with results which the clinician might regard as abnormal and not to provide an estimate of the "normal" or "reference" range, some adjustments were made to these ranges to ensure comparability with the reference ranges used in the hospital.

A similar procedure was used to assess the outcome in both trials. Every component in each profile scrutinized was classified as follows: (1) result within the range (as described above); (2) outlying result (3) no result. Results outside the ranges were classified as (a) requested independently by the clinician, $(b)$ not requested by the clinician, or (c) erroneous (due to technical problems). Those results that were not requested by the clinician were subdivided as (i) expected, child known to have a disorder which would affect the result; (ii) diagnostic, a result leading to a new diagnosis; or (iii) unexplained. When a new diagnosis was made as a direct result of the profile it was recorded together with any treatment given. Only the clinician's interpretation of the results of the profile was used in the assessment. For instance, a diagnosis was attributable to the profile only when either there was a clear statement in the notes to this effect or further tests confirmed the abnormality and elucidated its cause.

The number of pathology requests and $x$-ray examinations during the first three weeks of the admission was recorded, the total for each week being noted individually. When the patient was in hospital for less than three weeks all requests up to three months were counted or until he was readmitted. Each request for a test or group of tests usually performed together (for example, liver function tests) counted as one unit.

\section{Results}

Altogether there were 5277 admissions during the period of the study, but on 1544 occasions no profile was constructed. The reasons were: insufficient blood (211 occasions); permission refused (572); recent operation or blood transfusion (562); discharged before blood could be collected (190); other (9). Profiles that were repeated because a child was readmitted are included in the analysis but 514 profiles were excluded for the following reasons: "immediate" group (43 profiles), report sent out after the fourth day in trial A or after the third day in trial B (398), other (73). Table II gives the number of profiles in the four groups of the trials. There were no statistically significant differences between the two groups in each trial in age distribution, sex ratio, or consultant under whom the child was admitted.

In trial A, 1129 profiles out of a total of 2430 showed one or more outlying values (see above), and the case notes of $1110(98 \%)$ of these patients were examined. In trial B, 781 profiles (99\%) out of 789 were reviewed, as also were those in the immediate group.

The total number of investigations performed on patients in both trials was 33 595. Table III gives the total number of investigations in each group of the trials and the total number of outlying results. The outlying results are subdivided into those requested independently by the clinician, those not requested, and those which were erroneous for technical reasons. The results that were not requested are further subdivided into (1) those which though not requested would have been expected because of previous investigations, (2) those leading to a new diagnosis, and (3) unexplained results. The results for patients whose case notes could not be found are listed as "not reviewed." There was no significant difference in the number of unexpected results (unexplained and diagnostic) between the early and late groups $\left(\chi^{2}=0.03 ;\right.$ D.F. $\left.=1 ; P>0.1\right)$.

TABLE III-Profile Investigations in Trials and Breakdown of Outlying Results (See Text)

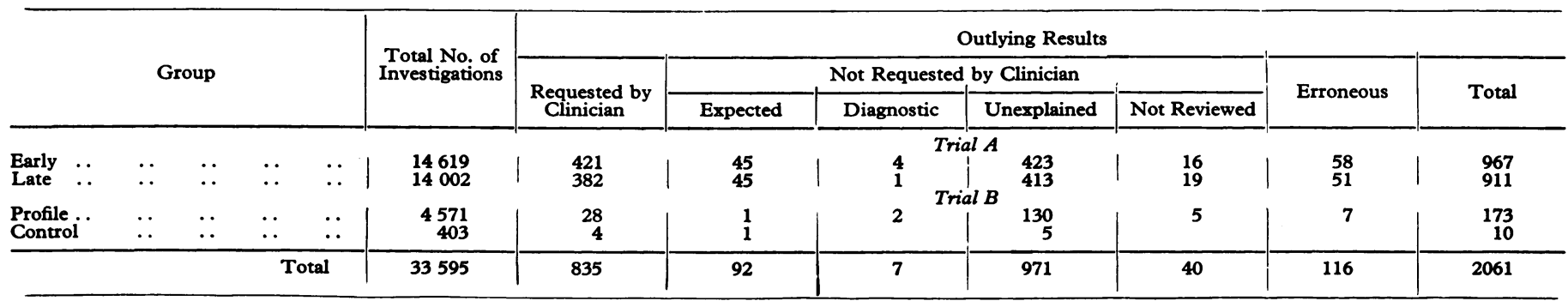




\section{DIAGNOSES AND OTHER EFFECTS OF PROFILE}

The profile led direct to 13 new diagnoses in 13 children (table IV), who were distributed among the groups of the trials as follows: trial A, early group 4 patients, late group 1 ; trial B, profile group 2 patients, control group none; and immediate group 6 patients. Eleven of the 13 children were treated for their condition, though in two only by changing the milk (table IV).

TABLE IV-New Diagnoses Made as Result of Profile in Thirteen Children

\begin{tabular}{|c|c|c|}
\hline Diagnosis & $\begin{array}{l}\text { No. of } \\
\text { Children }\end{array}$ & Treatment \\
\hline $\begin{array}{l}\text { Rickets } \\
\text { Hypocalcaemia (neonatal)... }\end{array}$ & $\begin{array}{l}2 \\
2\end{array}$ & $\begin{array}{l}\text { Vitamin D } \\
\text { Intravenous calcium (1 patient), } \\
\text { oral calcium (1 patient) }\end{array}$ \\
\hline $\begin{array}{l}\text { Renal osteodystrophy } \\
\text { Familial hypercholesterolaemia } \\
\text { Hypoalbuminaemia } \\
\text { Hyperammonaemia }\end{array}$ & $\begin{array}{l}1 \\
2 \\
2 \\
1 \\
1 \\
2\end{array}$ & $\begin{array}{l}\text { Vitamin D } \\
\text { Diet } \\
\text { Infusion of albumin (1 patient) } \\
\text { Diet } \\
\text { No special treatment } \\
\text { Milk changed }\end{array}$ \\
\hline
\end{tabular}

\section{TIME SPENT IN HOSPITAL}

It has been stated $^{3}$ that profiles may shorten the stay in hospital because the results are available soon after admission. We found no significant difference in the mean time spent in hospital between the early and late groups in trial A (8.4* and 8.6 days respectively; $t=0.51, \mathrm{P}>0.1)$ or between the profile and control groups in trial $\mathrm{B}(3.7$ and 3.4 days respectively; $t=1 \cdot 47, \mathrm{P}>0.1)$.

\section{NUMBER OF PATHOLOGY REQUESTS}

In trial $\mathbf{A}$, in which a profile was constructed for all the patients, there was no significant difference between the early and late groups in the total number of investigations requested (early group : 565 admissions, 8958 requests; late group: 545 admissions, 7966 requests $\chi^{2}=1 \cdot 72$, D.F. $\left.=1, P>0 \cdot 1\right)$. But when the investigations were separated into the four time periods (weeks 1,2 , and 3 and up to three months; see above) the difference between the early and late groups was significant (table V; $\chi^{2}=13.42, \mathrm{D} . \mathrm{F} .=3, \mathrm{P}<0.01$ ).

Further breakdown of the results into chemical pathology requests and all other investigations (table V) showed a significant difference between the early and late groups in chemical pathology requests $\left(\chi^{2}=13.28\right.$, D.F. $\left.=3, P<0.01\right)$ but not in other investigations.

TABLE v-Trial A. Pathology Requests for Patients with Outlying Values in Profile during and after Admission

\begin{tabular}{|c|c|c|c|c|c|c|}
\hline \multirow{2}{*}{ Group } & \multicolumn{3}{|c|}{ Week: } & \multirow{2}{*}{$\begin{array}{l}\text { Up to } \\
3 \text { Months }\end{array}$} & \multirow{2}{*}{ Total } & \\
\hline & 1 & 2 & 3 & & & \\
\hline \multicolumn{7}{|c|}{ Chemical Pathology Requests } \\
\hline $\begin{array}{l}\text { Early } \\
\text { Late }\end{array}$ & $\begin{array}{l}2325 \\
2045\end{array}$ & $\begin{array}{l}633 \\
530\end{array}$ & $\begin{array}{l}351 \\
283\end{array}$ & $\begin{array}{l}84 \\
119 \\
\text { Other } R\end{array}$ & $\begin{array}{r}3393 \\
2977 \\
\text { quests }\end{array}$ & $x^{2}=13.28 ;$ D.F. $=3 ; P<0.01$ \\
\hline $\begin{array}{l}\text { Early } \\
\text { Late }\end{array}$ & $\begin{array}{l}3917 \\
3571\end{array}$ & $\begin{array}{l}908 \\
825\end{array}$ & $\begin{array}{l}556 \\
421\end{array}$ & $\begin{array}{l}184 \\
172 \\
\text { All req }\end{array}$ & $\begin{array}{l}5565 \\
4989 \\
\text { uests }\end{array}$ & $x^{2}=3 \cdot 12 ;$ D.F. $=3 ; P>0.05$ \\
\hline $\begin{array}{l}\text { Early } \\
\text { Late }\end{array}$ & $\begin{array}{l}6242 \\
5616\end{array}$ & $\begin{array}{l}1541 \\
1355\end{array}$ & $\begin{array}{l}907 \\
704\end{array}$ & $\begin{array}{l}268 \\
291\end{array}$ & $\begin{array}{l}8958 \\
7966\end{array}$ & \}$x^{2}=13.42 ;$ D.F. $=3 ; P<0.01$ \\
\hline
\end{tabular}

TABLE vi-Trial B. Pathology Requests during and after Admission (See Text)

\begin{tabular}{|c|c|c|c|c|}
\hline \multicolumn{2}{|c|}{ Group } & $\begin{array}{l}\text { No. of } \\
\text { Admissions }\end{array}$ & $\begin{array}{l}\text { No. of } \\
\text { Requests }\end{array}$ & \\
\hline \multicolumn{5}{|c|}{ Chemical Pathology Requests } \\
\hline $\begin{array}{l}\text { Profile .. } \\
\text { Control }\end{array}$ & $\therefore 1$ & $\begin{array}{l}382 \\
399\end{array}$ & $\begin{array}{l}182 \\
120 \\
1\end{array}$ & \}$x^{2}=11.25 ;$ D.F. $=1 ; P<0.001$ \\
\hline $\begin{array}{l}\text { Profile } \\
\text { Control }\end{array}$ & $\because .1$ & $\begin{array}{l}382 \\
399\end{array}$ & $\mid \begin{array}{l}\quad 616 \\
568 \\
\text { All Requests }\end{array}$ & $\chi^{2}=1.83 ;$ D.F. $=1 ; P>0.05$ \\
\hline $\begin{array}{l}\text { Profile } \\
\text { Control }\end{array}$ & $\because$ & $\begin{array}{l}382 \\
399\end{array}$ & $\begin{array}{l}798 \\
688\end{array}$ & $x^{2}=4.70 ;$ D.F. $=1 ; P<0.05$ \\
\hline
\end{tabular}

*As the frequency distribution of the data had a pronounced positive skew which was satisfactorily normalized by a logarithmic transformation all calculations were made using this transformation. Difference between names was tested with an unpaired $t$ test.
In trial B there were more investigations in the profile group than in the control group (table VI; $\chi^{2}=4.70, \mathrm{D} . \mathrm{F} .=1, \mathrm{P}<0.05$ ). Subdivision of the investigations into chemical pathology requests and all others (table VI) showed significantly more chemical pathology requests in the profile group than in the control group $\left(\chi^{2}=11 \cdot 25\right.$; D.F. $=1 ; P<0.001)$ but no difference for the other investigations.

\section{Discussion}

Studies of the use of biochemical profiles for adults have shown that unsuspected abnormalities may be found that are responsible for new and important diagnoses. Exact comparisons between the findings of different surveys are not possible as the tests making up the profiles have not all been the same and different methods of assessment have been used. For example, the assessment in the study by Bryan et al. ${ }^{1}$ was done by members of the team, who examined the patient and the case notes, but in Whitehead's survey ${ }^{3}$ the clinician responsible for the patient filled in a questionnaire. Despite these and other differences the findings do show some similarities. Bryan et al. ${ }^{1}$ thought that $5-10 \%$ of the patients benefited direct. Whitehead ${ }^{3}$ estimated that in $8.3 \%$ of the patients a new diagnosis was made, while Young and Drake ${ }^{5}$ made a new diagnosis in $2.7 \%$.

In our study 2816 children were examined but in only 13 $(0.46 \%)$ was a new diagnosis made. In six of these there was, on scrutiny of the notes in retrospect, a clear indication of the disorder in the clinical history. One of the children with familial hypercholesterolaemia had a strong family history of early ischaemic heart disease, and both cases of rickets were in highrisk groups. Several factors may have contributed to the small number of diagnoses.

\section{POPULATION EXAMINED}

Daughaday et al. ${ }^{2}$ showed that the proportion of patients with significant abnormalities in the profiles was three times greater in the over-70s than in those aged up to 29 years. Many of the diagnoses in adult series ${ }^{1-35-7}$ have been maturity-onset diabetes and hyperuricaemia, neither of which would be expected in children.

\section{FOLLOW-UP OF "ABNORMAL" RESULTS}

It is unusual to be able to make a definite diagnosis from the results of the profile; they act only as pointers, so that further tests are almost always needed to elucidate their full meaning. As the clinicians continued to request all the pathology investigations they thought necessary, any increase in requests was a measure of the extent to which the profile results were followed up. In trial $B$, in which a profile was compared with a haemoglobin estimation alone, there was an increase in the total number of requests (table VI). In trial A, both groups had a profile constructed, so that the total number of requests would not be expected to differ (table V). There was, however, a statistically significant variation from week to week (table V), which was thought to be due to the extra investigations ordered as a result of the profile. Chemical pathology requests were responsible for most of the extra tests (tables $\mathrm{V}$ and $\mathrm{VI}$ ).

A special study of 20 children with cholesterol values greater than $5.96 \mathrm{mmol} / 1$ in the profile was conducted during the investigation. When these children are excluded from the analysis the difference in the number of chemical pathology requests in trial A (16 children) between the early and late groups is no longer statistically significant $\left(\chi^{2}=3.12 ; \mathrm{D} . \mathrm{F} .=3 ; \mathrm{P}>0 \cdot 1\right.$ ). In trial B ( 4 children) the difference in the number of chemical pathology requests is still significant but the $\chi^{2}$ value $(D . F .=1)$ is reduced from $11.25(P<0.001)$ to $4.02(0.05$ $>\mathrm{P}>0.025)$. We conclude that the investigations performed on this small group of patients made a major contribution to the observed differences in the total number of pathology requests and that therefore the clinicians as a whole ordered very few extra investigations. As a matter of deliberate policy there was little contact between those responsible for the profile in the laboratory and the clinicians, whose opinion was not sought about the results of the profile. The results were discussed only at the clinician's request. This probably reduced the number of new diagnoses. Williamson et al. ${ }^{8}$ measured clinicians' responses to the results of three routine screening tests (blood sugar, haemoglobin, and urine examination) and showed that the findings 
of these tests were largely ignored. Attempts to educate those who should take action were unsuccessful. Only when steps were taken to draw attention to the results by covering them up were more results followed up. Effective methods are therefore needed to ensure that the results of such profiles are carefully noted and that the implications of the results are fully understood.

\section{LACK OF REFERENCE VALUES}

In all biochemical profile studies bordesline results constitute a considerable problem, even when the reference ranges are well recognized. In children there is little information about these ranges or on the factors that influence them. For example, several values show a definite trend with age (phosphorus, alkaline phosphatase, SGOT). Thus potentially important abnormalities may easily be overlooked.

In most studies of adults' biochemical profiles ${ }^{1-3} 6^{-7}$ the clinician received the profile soon after admission and before all those responsible for the patient discussed his condition. In such studies it is often difficult to decide what proportion of profile abnormalities were truly unexpected and would have remained undiscovered. Probably the number of diagnoses attributed to the profile under these circumstances would be overestimated. Our two trials were designed to avoid this difficulty by using control groups in which either the information was withheld or no profile was constructed. The number of new diagnoses was so small in the test and control groups, however, that it is not possible to say whether withholding information reduced the number of diagnoses attributed to the profile.

\section{Conclusions}

The profile made only a small contribution to the overall care of the patient. Nevertheless, the introduction of profiles may be the only way in which a laboratory can cope with its routine work load. We emphasize the importance, in these circumstances, of educating the clinicians to whom the profiles are sent in the use of large quantities of "unsolicited information" and of ensuring that the results are scrutinized carefully.

We thank Miss Anne Warren and Mr. D. A. Smith for technical help, Mrs. Anne Sprigge and Mrs. Joy Fitzgerald for help in collecting the blood samples, Mr. P. Jenkins for technical advice, Mr. A. J. Westlake for help with the computing and statistics, and Mrs. Mary Lambert for finding the case notes. The work was supported by a grant from the Department of Health and Social Security.

\section{References}

1 Bryan, D. J., et al., Clinical Chemistry, 1966, 12, 137.

2 Daughaday, W. H. et al in Multiple Laboratory Screening, ed. E. S. Benson and P. E., et al., in Multiple Laboratory Screening, ed. E. S. Benson and P. E. Strandjord. p. 181., New York, Academic Pres,

3 Whitehead, T. P., Advances in Clinical Chemistry, 1971, 14, 389.

4 Leonard, J. V., Annals of Clinical Biochemistry. In press.

Young, D. M., Drake, N., and Weir, R. J., Canadian Medical Association Fournal, 1968, 98, 868 .

${ }^{6}$ Belliveau, R. E., Fitzgerald, J. E., and Nickerson, D. A., American Fournal of Clinical Pathology, 1970, 53, 447.

'Alerte, F. C., in Automation in Analytical Chemistry, Technicon Symposium, p. 345. New York, Mediad, 1966.

${ }^{8}$ Williamson, J. W., Alexander, M., and Miller, G. E., Fournal of the American Association, 1967, 201, 938.

\title{
Placental Transmission of Thyroid-stimulating Immunoglobulins
}

\author{
S. M. DIRMIKIS, D. S. MUNRO
}

British Medical fournal, 1975, 2, 665-666

\section{Summary}

Long-acting thyroid stimulator (LATS) and LATS protector (LATS-P) were assayed at or near delivery in serum from 18 pregnant women with a history of past or present thyrotoxicosis. The results suggested that neonatal thyrotoxicosis may be predicted prenatally if maternal serum LATS and LATS-P concentrations near delivery are above certain levels.

\section{Introduction}

Until recently it was generally considered ${ }^{1}$ that neonatal hyperthyroidism was caused by the placental transmission of the long-acting thyroid stimulator (LATS) which is an immunoglobulin $G$ (IgG). The serum of mother and affected infant usually contained detectable LATS activity and the clinical course of the disease seemed to be related to the serum LATS

Section of Medicine, Academic Division of Medicine, The University, Sheffield S10 2TN

S. M. DIRMIKIS, M.SC., PH.D., Senior Experimental Officer

D. S. MUNRO, M.D., F.R.C.P., Sir Arthur Hall Professor of Medicine activity in the neonate. The levels of maternal LATS reported, however, have varied widely.

Three recent reports have shown that LATS-protector (LATS-P), an IgG which seems to stimulate only the human thyroid, may also cause neonatal hyperthyroidism. There have been two cases of neonatal thyrotoxicosis in which LATS was undetectable in either mother or infant; LATS-P was detectable in maternal serum two years after the birth of the affected infant in one case ${ }^{2}$ and 10 years after in the other. ${ }^{3}{ }^{4}$ Dirmikis et al. ${ }^{5}$ reported the first case of LATS-negative neonatal hyperthyroidism in which LATS-P was detected in both maternal and cord blood.

We report here the results of simultaneous serum LATS and LATS-P determinations in 18 pregnant women with a history of Graves's disease. In several cases the infant's serum was also assayed.

\section{Patients and Methods}

Twenty women were studied, 19 with an unequivocal history of present or past Graves's disease. The remaining patient (case 19) had previously given birth to an infant with neonatal thyrotoxicosis. ${ }^{3}$ The clinical diagnosis of Graves's disease was confirmed in all cases by thyroid function tests (including radioiodine uptake, protein bound iodine, and serum T4 estimations, T3 resin uptake, and thyrotrophin releasing hormone test).

Eighteen patients gave birth to infants during this investigation, and two (cases 19 and 20 ) had previously given birth to infants with neonatal thyrotoxicosis. Five of the 18 infants born during this 